\title{
Seasonal differences in growth, photosynthetic pigments and gas exchange properties in two greenhouse grown maize (Zea mays L.) cultivars
}

\author{
Igbal Hussain $^{1 *}$, Abdul Wahid ${ }^{2}$, Rizwan Rasheed ${ }^{1}$, Hafiz Muhammad Akram ${ }^{3}$ \\ ${ }^{1}$ Department of Botany, Govt. College University, Faisalabad-38000, Pakistan \\ ${ }^{2}$ Department of Botany, University of Agriculture, Faisalabad-38040, Pakistan \\ ${ }^{3}$ Plant Physiology Section, Agronomic Research Institute, AARI, Faisalabad-38850, \\ Pakistan
}

\begin{abstract}
The greenhouse (GH) effect has emerged as a major factor in changing cropping patterns and limiting crop yields. This study was conducted to determine the comparative growth and photosynthetic responses of selected heat-resistant (cv. Sadaf) and heat-susceptible (cv. Agatti-2002) cultivars of maize to simulated GH conditions during spring and autumn seasons at seedling, silking and grain filling stages in 2007. Fifteen day old plants were shifted to plexiglass-fitted canopies to create GH conditions and data were recorded at each growth stage. The results revealed that the seasons, GH conditions and cultivars had large effects on plant growth and photosynthetic attributes. Simulated GH conditions increased the canopy temperature $4-7{ }^{\circ} \mathrm{C}$ in spring and $3-5^{\circ} \mathrm{C}$ in autumn, but increased relative humidity by $2-3 \%$ in spring and $5-9 \%$ in autumn season. Although GH reduced the growth of both cultivars, shoot dry mass was reduced more in spring grown heat-susceptible maize at all growth stages. Although the cultivars showed a decrease in growth and photosynthesis, GH conditions resulted in less damage to cv. Sadaf than cv. Agatti-2002 in both seasons. Major indicators of sensitivity to GH effect were loss of chlorophyll $b$ and carotenoids, reductions in net photosynthesis and stomatal conductance, and possibly reduced ability of Rubisco to fix $\mathrm{CO}_{2}$ in sensitive maize.
\end{abstract}

Keywords: canopy temperature, gas exchange, greenhouse effect, growth, maize, photosynthesis

\begin{abstract}
Abbreviations: $\mathrm{Car}-$ carotenoid, $\mathrm{C}_{\mathrm{i}}-$ leaf substomatal $\mathrm{CO}_{2}$ concentration, Chl- $a$ - chlorophyll $a$, Chl- $b$ - chlorophyll $b$, Chls - total chlorophylls, E - leaf transpiration rate, GH - greenhouse, $\mathrm{g}_{\mathrm{s}}$ - stomatal conductance, PAR - photosynthetically active radiations, $\mathrm{P}_{\mathrm{n}}-$ net photosynthesis
\end{abstract}

* Corresponding author, e-mail: iqbalbotanist1@yahoo.com 


\section{Introduction}

The greenhouse (GH) effect on plants arising from the increased concentration of greenhouse gases and resulting in increased ambient temperature has emerged as a major growthlimiting factor for most crop plants. The GH effect results in increased canopy temperature that causes reduction of plant biomass (Blum 1988, Hussain et al. 2010). Heat stress directly alters photosynthetic acclimation and physiological processes and indirectly changes the pattern of development (MAнмOOD et al. 2012, ARBONA et al. 2013). In different studies, high temperature caused a decrease in growth, transpiration, respiration and photosynthesis and final economic yield (Karim et al. 2000, StONE 2001).

Optimal photosynthesis has a fundamental importance for the carbon accumulation, growth and biomass production of different plant species. Sub-optimal growth conditions affect all the aspects of photosynthesis. High temperature significantly inhibits net photosynthesis $\left(\mathrm{P}_{\mathrm{n}}\right)$ and stomatal conductance $\left(\mathrm{g}_{\mathrm{s}}\right)$ in many plant species (CRAFTS-BRANDNER and Salvucci 2002, Morales et al. 2003). The $\mathrm{P}_{\mathrm{n}}$ in developed and nearly developed leaves was more sensitive than in developing leaves (KARIM et al. 1999). Photosynthetic apparatus is highly sensitive to high temperature and inhibited when the leaf temperature exceed $38^{\circ} \mathrm{C}$ (CRAFts-Brandner and SalvucCi 2002). High temperature reduces the activation state of Rubisco, which is the most susceptible component of the photosynthetic apparatus in both $\mathrm{C}_{3}$ and $\mathrm{C}_{4}$ plants (Crafts-Brandner and Salvucci 2002, Salvucci and Crafts-Brandner 2004, Luo et al. 2011). Extensive studies have shown that both photosystems are damaged by increasing temperature during photosynthesis, thus leading to reduced photosynthetic efficiency (SziLviA et al. 2005, Du et al. 2011).

Maize (Zea mays L.) is a $\mathrm{C}_{4}$ plant and has a distinctive leaf anatomy and photosynthetic metabolism (TAIZ and ZEIGER 2010). Both photosynthesis and growth of $\mathrm{C}_{4}$ plants respond positively towards elevated ambient $\mathrm{CO}_{2}$ (GHAnNoum et al. 2000). The rate of leaf development and $\mathrm{P}_{\mathrm{n}}$ in maize is at maximum near 31 to $34{ }^{\circ} \mathrm{C}$ (TollenaAr 1989, Yan and Hunt 1999, Kim et al. 2007) at ambient $\mathrm{CO}_{2}$, but decreased at temperatures above $37^{\circ} \mathrm{C}$ while complete inhibition occurred near $45^{\circ} \mathrm{C}$ (Crafts-Brandner and SALVucCi 2002). However, there are great intraspecific differences in maize for tolerance to ambient environmental changes.

In the era of climate change, the GH effect has attained major importance and thus led scientists to study precisely its influence on the photosynthetic properties of important crop species. To adapt to changes in the environment, plants have evolved a number of physiological and biochemical strategies. Leaf photosynthesis plays an important role in the adaptation of plants to changing environmental conditions, but this also depends upon the type of species and the growth stage. Limited reports have highlighted the specific growth and photosynthetic responses of plants to current and upcoming changes in the climatic conditions. The present study was undertaken to determine the changes in growth, pigment composition and gas exchange attributes of selected differentially heat-responsive maize cultivars grown in $\mathrm{GH}$ conditions.

\section{Materials and methods}

\section{Source of maize seed, treatment and plant growth conditions}

Seeds of selected maize (Zea mays L.) cultivars Sadaf (heat-tolerant) and Agatti-2002 (heat-sensitive) were obtained from the Maize and Millets Research Institute (MMRI), 
Yousafwala, Sahiwal, Pakistan. The experiments were conducted in the wire-house of the Department of Botany, University of Agriculture, Faisalabad, Pakistan during the spring and autumn seasons of 2007. Seeds of both cultivars were grown in plastic pots, $30 \mathrm{~cm}$ high, 82 $\mathrm{cm}$ in circumference at the top and $70 \mathrm{~cm}$ at the bottom. A hole was made in the bottom for leaching during replacement of the soil solution. Each pot contained $13 \mathrm{~kg}$ of dry sand, which was washed thoroughly with tap water followed by distilled water before filling in the pots. Ten seeds of both cultivars were sown. After germination, the pots were given half strength nutrient solution (HOAGLAND and ARNON 1950) after four days in an amount to drain the previous solution. Five healthy and equal sized, three-day old seedlings were retained in each pot for making determinations at seedling, silking and grain filling stages. Greenhouse conditions were created by shifting the pots containing growing plants to the canopies that were placed in a wire-house at the above growth stages, whilst the control set was kept outside the canopies in a wire-house. The top of the wire- house was covered with polythene sheeting to produce the light transmission index of 75 to $80 \%$ in and outside the canopy. Moreover, by measuring PAR using an open system portable infrared gas analyzer (IRGA; LCA-4, Analytical Development Company, Hoddesdon, England), it was noticed that the plants inside and outside the canopy had PAR $(400-700 \mathrm{~nm})$ at the leaf surface in the range 1185-1204 $\mu \mathrm{mol} \mathrm{m} \mathrm{m}^{-2} \mathrm{~s}^{-1}$ between 10 and $11 \mathrm{am}$. The temperatures and relative humidity inside and outside the canopies were recorded in both the seasons just above the plant height (Fig. 1). The plants were kept inside the canopies for 20 days at each of the growth stages, and harvesting was done after 15 days of treatment application.
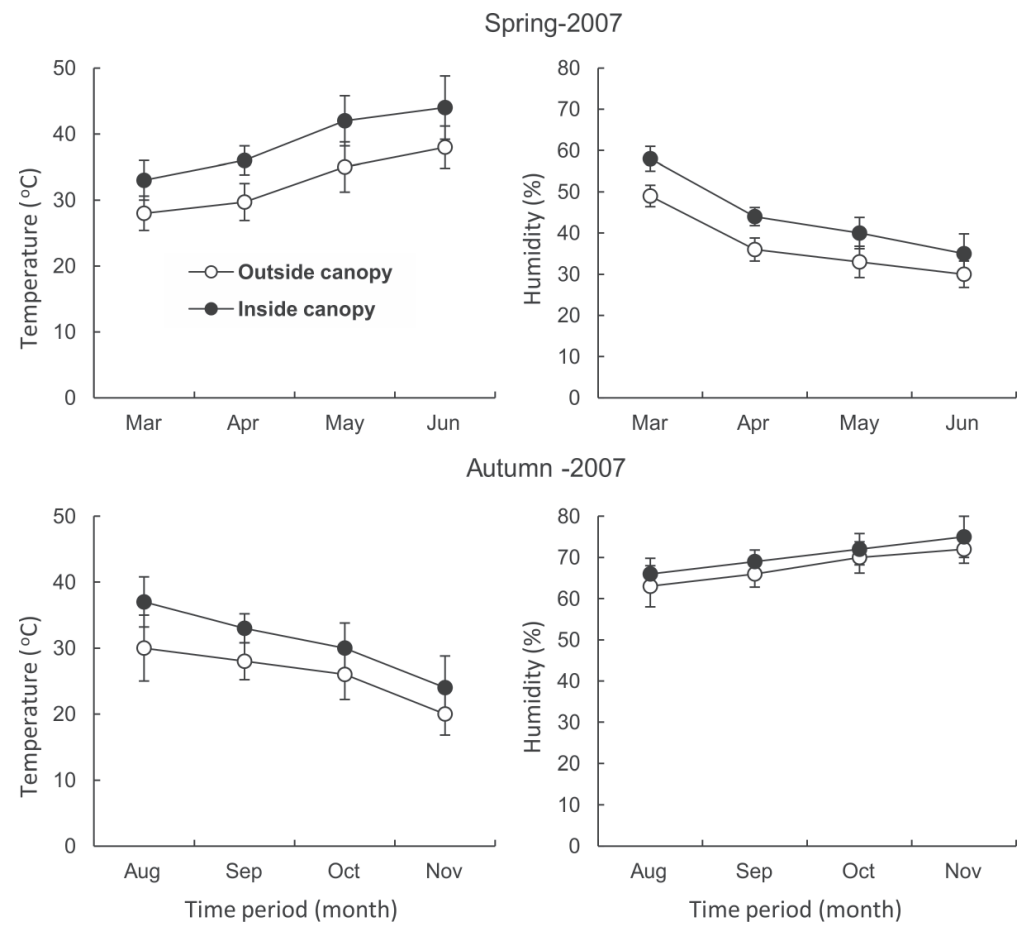

Fig. 1. Variation in the temperature and relative humidity inside and outside the plexiglass fitted canopy during an experiment in spring and autumn seasons in 2007. 
For the determination of Chl- $a$, Chl- $b$, their total and total carotenoid (Car) contents, the third leaf $(0.5 \mathrm{~g})$ from the top was excised and homogenized with pestle and mortar in $80 \%$ acetone; volume was made up to $5 \mathrm{~mL}$ and filtered. The absorbance was measured at 480 $\mathrm{nm}$ for Car, and at 645 and $663 \mathrm{~nm}$ for Chl- $a$ and Chl- $b$, respectively, using a spectrophotometer (Hitachi-U-2001, Japan). Chl- $a$, Chl- $b$, their total content and their Chl- $a$ :Chl- $b$ ratio were calculated as described by Yoshida et al. (1976), while Car were computed with the formula of DAVIES (1976).

Gas exchange characteristics were measured by IRGA of the third leaf (from the top) of each plant. Measurements were performed from 10:00 am to 11:00 am with the following leaf chamber adjustments: leaf surface area $11.35 \mathrm{~cm}^{2}$, ambient $\mathrm{CO}_{2}$ concentration 357 $\mu \mathrm{mol} \mathrm{mol}{ }^{-1}$, temperature of leaf chamber varied from 32.5 to $37^{\circ} \mathrm{C}$, leaf chamber gas flow rate $392.8 \mathrm{ml} \mathrm{min}^{-1}$, molar flow of air per unit leaf area $440 \mu \mathrm{mol} \mathrm{m} \mathrm{m}^{-2} \mathrm{~s}^{-1}$, ambient pressure $99.6 \mathrm{kPa}$, water vapor pressure in to chamber ranged from 20.5 to $23.1 \mathrm{mbar}$, PAR (Q leaf) on leaf surface ranged from 975 to $1250 \mu \mathrm{mol} \mathrm{m}^{-2} \mathrm{~s}^{-1}$.

\section{Statistical analysis}

The experimental design was completely randomized with four replications per treatment. The presence or absence of significant differences between different factors at $\mathrm{P}=$ 0.05 was ascertained with analysis of variance (ANOVA). The means were compared to find significant differences among them using least significant difference. Computer software COSTAT (CoHort software, 2003, Monterey, California, USA) was used for all statistical analysis and MS-Excel was used to graphically present the data.

\section{Results}

\section{Plant dry mass}

Data for changes in shoot dry weight indicated significant $(\mathrm{P}<0.01)$ difference in cultivars and growth stages during spring but not during autumn. However, for root dry weight, such an interaction was notable at silking and grain filling stages in spring only (Tab. 1). Shoot dry weight during spring was reduced at seedling stage in both cultivars, although cv. Sadaf indicated a lower reduction (10\%) than cv. Agatti-2002 (39\%) in GH conditions. At silking stage, cv. Sadaf showed an increase (5\%) and cv. Agatti-2002 a decrease (36\%) in shoot dry weight. At grain filling stage, shoot dry weight was reduced in both cultivars, but this reduction was lower (3\%) in cv. Sadaf than in cv. Agatti-2002 (30\%). In autumn, although the trend of changes in shoot dry weight was similar to that observed during spring, except at the grain filling stage when cv. Sadaf indicated an increase while cv. Agatti-2002 showed a decrease in shoot dry weight under GH conditions. Root dry weight declined in both cultivars although the reduction was less $(\sim 18 \%)$ in cv. Sadaf than in cv. Agatti-2002 $(\sim 26 \%)$ during spring at the seedling stage. At silking and grain filling stages, cv. Sadaf showed an increase ( $~ 8$ and 5\%, respectively) and cv. Agatti-2002 a decrease (34 and 32\%, respectively) in root dry weight. In autumn, there was a reduction of root dry weight in both cultivars but cv. Agatti-2002 suffered more than cv. Sadaf ( $\sim 22$ and 6\%, respectively). At silking and grain filling stages, cv. Sadaf showed an increase ( 41 and $4 \%$, respectively) but cv. Agatti-2002 a decrease ( 20 and 34\%, respectively) in root dry weight. 
Tab. 1. Effect of greenhouse conditions on dry weight of maize plants grown during spring and autumn in 2007. The comparisons have been made of the cultivars separately for seasons and growth stages. The values sharing same letter differ non-significantly $(\mathrm{P}>0.05)$.

\begin{tabular}{|c|c|c|c|c|c|c|}
\hline \multirow{2}{*}{ Seasons } & \multirow{2}{*}{ Growth stages } & \multirow{2}{*}{ Cultivars } & \multicolumn{2}{|c|}{ Shoot dry weight (g) } & \multicolumn{2}{|c|}{ Root dry weight (g) } \\
\hline & & & Control & Greenhouse & Control & Greenhouse \\
\hline \multirow{6}{*}{ Spring } & \multirow{2}{*}{ Seedling } & Sadaf & $3.82^{\mathrm{a}}$ & $3.43^{b}$ & $1.65^{\mathrm{a}}$ & $1.36^{\mathrm{a}}$ \\
\hline & & Agatti-2002 & $3.02^{\mathrm{c}}$ & $1.84^{\mathrm{d}}$ & $1.89^{\mathrm{a}}$ & $1.40^{\mathrm{a}}$ \\
\hline & \multirow{2}{*}{ Silking } & Sadaf & $17.52^{\mathrm{a}}$ & $18.44^{\mathrm{a}}$ & $3.82^{\mathrm{a}}$ & $4.12^{\mathrm{a}}$ \\
\hline & & Agatti-2002 & $15.85^{\mathrm{ab}}$ & $10.12^{\mathrm{c}}$ & $3.27^{\mathrm{b}}$ & $2.16^{\mathrm{c}}$ \\
\hline & \multirow{2}{*}{ Grain filling } & Sadaf & $60.93^{\mathrm{a}}$ & $58.89^{\mathrm{ab}}$ & $11.67^{\mathrm{abc}}$ & $12.24^{\mathrm{ab}}$ \\
\hline & & Agatti-2002 & $49.52^{\mathrm{bc}}$ & $34.64^{\mathrm{d}}$ & $11.86^{\mathrm{abc}}$ & $8.06^{\mathrm{c}}$ \\
\hline \multirow{6}{*}{ Autumn } & \multirow{2}{*}{ Seedling } & Sadaf & $4.90^{\mathrm{a}}$ & $4.09^{\mathrm{a}}$ & $1.80^{\mathrm{a}}$ & $1.69^{\mathrm{a}}$ \\
\hline & & Agatti-2002 & $3.18^{\mathrm{a}}$ & $3.03^{\mathrm{a}}$ & $1.84^{\mathrm{a}}$ & $1.44^{\mathrm{a}}$ \\
\hline & \multirow{2}{*}{ Silking } & Sadaf & $13.84^{\mathrm{b}}$ & $15.52^{\mathrm{ab}}$ & $3.24^{\mathrm{a}}$ & $4.57^{\mathrm{a}}$ \\
\hline & & Agatti-2002 & $13.05^{\mathrm{bc}}$ & $12.83^{\mathrm{bc}}$ & $2.88^{\mathrm{a}}$ & $2.63^{\mathrm{a}}$ \\
\hline & \multirow{2}{*}{ Grain filling } & Sadaf & $50.02^{\mathrm{b}}$ & $51.40^{\mathrm{ab}}$ & $12.90^{\mathrm{ab}}$ & $13.44^{\mathrm{a}}$ \\
\hline & & Agatti-2002 & $55.90^{\mathrm{a}}$ & $39.50^{\text {cd }}$ & $13.78^{\mathrm{a}}$ & $9.16^{\mathrm{bc}}$ \\
\hline
\end{tabular}

\section{Photosynthetic pigments}

The GH conditions differentially modulated the contents of photosynthetic pigments in both maize cultivars. In the case of Chl- $a$, no significant $(\mathrm{P}>0.05)$ interaction of cultivars and growth conditions under the GH effect was noted at seedling stage in the spring season, at silking stage in both seasons and grain filling stage during autumn. The seedling stage data showed that cv. Sadaf showed no significant differences in both seasons, whilst cv. Agatti-2002 indicated a decline of $\sim 7$ and $21 \%$, respectively in both of the seasons in GH conditions. At silking stage, Chl- $a$ was not changed in cv. Sadaf but decreased $(\sim 18 \%)$ in cv. Agatti-2002 during spring while it increased by 7 and 11\% in both cv. Sadaf and cv. Agatti-2002 in autumn, respectively. At grain filling stage in spring, cv. Sadaf exhibited an increase (4\%) but cv. Agatti-2002 a decrease ( 14\%) of Chl-a. However, the responses of the two cultivars were similar in autumn in GH conditions (Fig. 2).

Data for changes in Chl- $b$ indicated no significant interaction $(\mathrm{P}>0.05)$ of cultivars and growth conditions at any growth stages under the $\mathrm{GH}$ effect. Data recorded at seedling stage indicated an increased Chl- $b$ by cv. Sadaf ( 4\%) during spring and autumn seasons, but cv. Agatti-2002 showed a decreased Chl- $b$ during spring (10\%) but no change during autumn. At silking stage, Chl- $b$ increased in cv. Sadaf during spring $(\sim 7 \%)$ but declined in autumn $(\sim 13 \%)$, whilst in cv. Agatti-2002 it declined in both seasons ( $\sim 16$ and $47 \%$ in spring and autumn, respectively). At grain filling stage, Chl- $b$ was reduced less in cv. Sadaf $(\sim 11 \%)$ than in cv. Agatti-2002 ( 21\%) during spring. In autumn, Chl- $b$ increased in cv. Sadaf $(\sim 14 \%)$ but did not change in cv. Agatti-2002 in GH conditions (Fig. 2).

Data for leaf total Chls content showed no significant $(\mathrm{P}>0.05)$ interaction of seasons and cultivars under prevailing GH conditions at any growth stage except during the spring at grain filling stage, when there was a significant $(\mathrm{P}<0.01)$ interaction for cv. Agatti-2002 


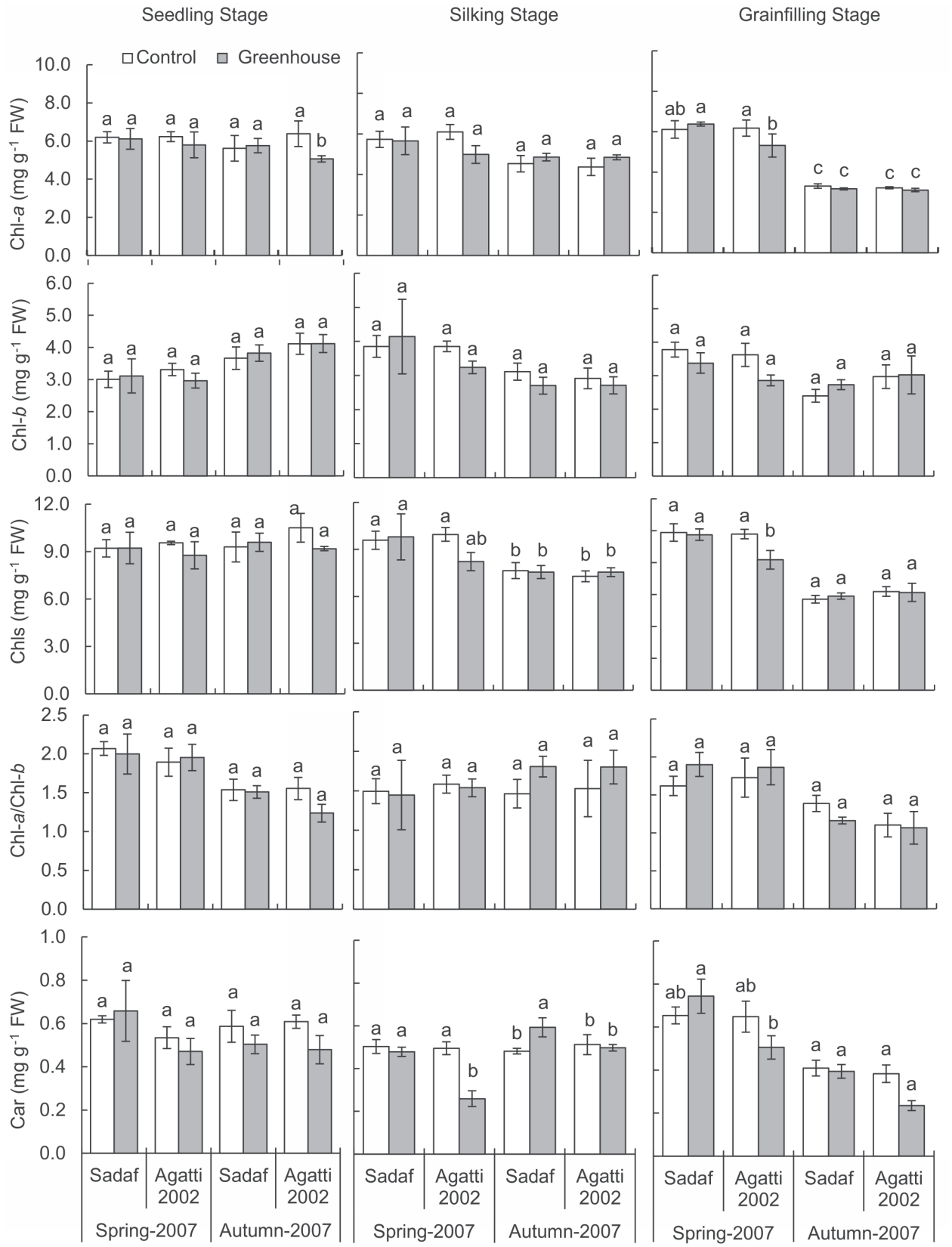

Fig. 2. Changes in photosynthetic pigments in the control and greenhouse grown plants of maize cultivars during spring and autumn seasons at three growth stages. The comparisons have been made of the cultivars separately for spring and autumn seasons, the data bars carrying same letter in a season differ non-significantly $(\mathrm{P}>0.05) ; \mathrm{FW}-$ fresh weight. 
cultivar. At seedling, silking and grain filling stages, cv. Sadaf showed similar amounts of total Chls in spring and autumn seasons, while cv. Agatti-2002 indicated a marked reduction in total Chls in autumn at seedling stage $(\sim 13 \%)$ and in spring at silking $(\sim 17 \%)$ and grain filling ( $\sim 16 \%$ ) stages under the GH effect (Fig. 2).

For Chl- $a$ /Chl- $b$ ratio, the interaction of cultivars and GH conditions were non-significant $(\mathrm{P}>0.05)$ at both seasons and all the growth stages. At seedling stage, cv. Sadaf revealed a significant reduction in the Chl- $a / \mathrm{Chl}-b$ ratio during both seasons, while cv. Agatti-2002 exhibited an increased Chl- $a$ /Chl- $b$ ratio $(\sim 3 \%)$ in spring and declined $(\sim 21 \%)$ in autumn under $\mathrm{GH}$ effect. At silking stage, there was an insignificant reduction $(\sim 3 \%)$ in $\mathrm{Chl}-$ $a /$ Chl- $b$ in cv. Sadaf during spring, but an increase ( $\sim 23 \%)$ during the autumn, while Agatti-2002 showed an insignificant reduction $(\sim 3 \%)$ in Chl- $a$ /Chl- $b$ ratio in spring and increased $(\sim 18 \%)$ during autumn under GH effect. At grain filling stage, cv. Sadaf showed an increased $(\sim 17 \%)$ Chl- $a$ /Chl- $b$ ratio during spring, but a reduction $(\sim 16 \%)$ during autumn, while in cv. Agatti-2002, this ratio was insignificantly increased $(\sim 8 \%)$ in spring and declined $(\sim 3 \%)$ during autumn.

Leaf Car content was affected significantly in cv. Agatti-2002 at silking stage during spring due to the $\mathrm{GH}$ effect. The interaction of cultivars and $\mathrm{GH}$ conditions was not significant $(\mathrm{P}>0.05)$ at seedling stage during either season, it was significant $(\mathrm{P}<0.01)$ during both seasons at silking stage, while at the grain filling stage the cultivars and GH condition interactions were significant during spring and non-significant $(\mathrm{P}>0.05)$ during autumn. At seedling stage, cv. Sadaf indicated an increase $(\sim 6 \%)$ of the Car during spring, but a reduction ( $\sim 14 \%$ ) during the autumn season, while cv. Agatti-2002 indicated a reduction of $\sim 12 \%$ during spring and of $\sim 21 \%$ in autumn under GH effect. At silking stage there was an insignificant reduction $(\sim 5 \%)$ in Car in cv. Sadaf during spring, but an increase $(\sim 23 \%)$ during autumn, while cv. Agatti-2002 showed a marked reduction ( 48\%) in Car in spring and an insignificant reduction ( $\sim 3 \%)$ during autumn under $\mathrm{GH}$ effect. At grain filling stage, cv. Sadaf again exhibited an increase $(\sim 14 \%)$ of Car during spring but an insignificant reduction ( $\sim$ \%) during the autumn season, while in Agatti-2002 a marked reduction was noted during spring ( 22\%) and autumn ( 39\%) (Fig. 2).

\section{Gas exchange parameters}

Leaf $\mathrm{P}_{\mathrm{n}}$ was significantly affected due to the $\mathrm{GH}$ effect and the response of cultivars was different at different growth stages attained in both the seasons. For this attribute, the interaction of cultivars and GH conditions were significant $(\mathrm{P}<0.05)$ at seedling stage in both seasons. At the seedling stage in the spring season, leaf $\mathrm{P}_{\mathrm{n}}$ decreased by $\sim 28 \%$ in $\mathrm{cv}$. Sadaf and showed a marked decline $(\sim 37 \%)$ in cv. Agatti-2002, while in autumn season there was a nominal reduction $(\sim 4 \%)$ in cv. Sadaf and a marked reduction $(\sim 21 \%)$ in cv. Agatti-2002. At silking and grain filling stages, although both the cultivars showed a reduction in $\mathrm{P}_{\mathrm{n}}$, a particularly significant reduction ( $\sim 60 \%$ and $\sim 57 \%$ ) was noted in cv. Agatti-2002 under the GH effect in both seasons (Fig. 3).

For leaf transpiration rate (E), the interactions of cultivars and GH conditions were nonsignificant $(\mathrm{P}>0.05)$ at both of seasons and growth stages (seedling and silking) except for a significant $(\mathrm{P}<0.05)$ interaction of cultivars and $\mathrm{GH}$ conditions at grain filling stage. $\mathrm{GH}$ conditions did not have effect in spring-grown plants in any of the maize cultivars at seedling stage (Fig. 3). At silking stage in the spring, no specific reduction in $\mathrm{E}$ in any of the 


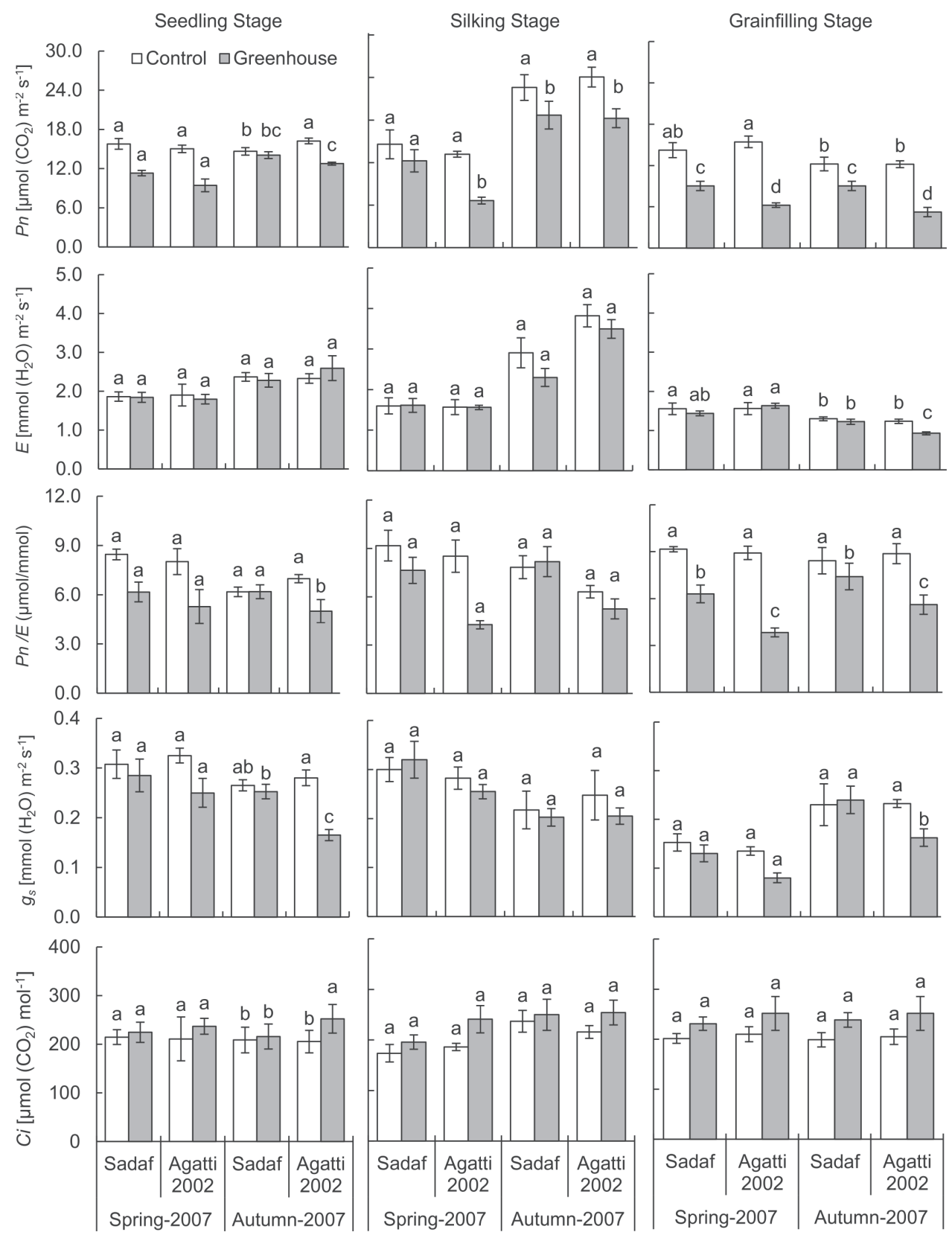

Fig. 3. Changes in gas exchange parameters of the control and greenhouse grown plants of maize cultivars during spring and autumn at three growth stages. The comparisons have been made of the cultivars separately for spring and autumn, the data bars carrying same letter in a season differ non-significantly $(\mathrm{P}>0.05)$. 
cultivars was recorded, while in autumn, a greater reduction $(\sim 20 \%)$ was evident in cv. Sadaf and a lesser one ( $9 \%)$ in cv. Agatti-2002 in GH conditions. At the grain filling stage E was the same as for silking stage in the spring for both cultivars and just slightly less than in the seedling stage. Only in autumn was E reduced ( 25\%) in cv. Agatti-2002 from the previously mentioned stages (Fig. 3).

In leaf water use efficiency, measured as $\mathrm{P}_{\mathrm{n}} / \mathrm{E}$, a significant interaction of cultivars and GH conditions was evident during the autumn at seedling stage $(\mathrm{P}<0.05)$ and at silking $(\mathrm{P}$ $<0.01)$ and grain filling $(\mathrm{P}<0.01)$ stages during both seasons. A greater reduction at seedling $(\sim 34 \%)$ and silking stage $(\sim 50 \%)$ was recorded in $\mathrm{P}_{\mathrm{n}} / \mathrm{E}$ due to $\mathrm{GH}$ effect in cv. Agatti-2002 than in cv. Sadaf in the spring. However, in the autumn, $\mathrm{P}_{\mathrm{n}} / \mathrm{E}$ was not affected in cv. Sadaf, but markedly reduced at seedling $(\sim 28 \%)$ and silking $(\sim 17 \%)$ stage in cv. Agatti-2002. At grain filling stage, this reduction in $\mathrm{P}_{\mathrm{n}} / \mathrm{E}$ was recorded in both maize cultivars in both the seasons, being much greater $(\sim 57 \%)$ during spring and $(\sim 43 \%)$ in autumn in cv. Agatti-2002 under the GH effect (Fig. 3).

The interaction of cultivars and GH conditions for leaf stomatal conductance $\left(\mathrm{g}_{\mathrm{s}}\right)$ was non-significant $(\mathrm{P}>0.05)$ for both seasons and all growth stages except during the autumn for seedlings and both seasons for the grain filling stage, which exhibited a significant $(\mathrm{P}<0.05)$ interaction of these factors. At the seedling stage $\mathrm{g}_{\mathrm{s}}$ was reduced slightly $(\sim 7 \%)$ in cv. Sadaf and greatly $(23 \%)$ in cv. Agatti-2002 during spring, while in autumn there was no great reduction in this attribute in cv. Sadaf although there was a marked reduction (41\%) in cv. Agatti-2002 in the GH. At the silking stage in the spring season, the $\mathrm{g}_{\mathrm{s}}$ increased $(7 \%)$ in cv. Sadaf but declined $(\sim 10 \%)$ in cv. Agatti-2002, while in the autumn season, both cultivars indicated declines in this attribute. At grain filling stage, GH conditions produced a little decline in the $\mathrm{g}_{\mathrm{s}}$ of cv. Sadaf ( 14\%) while cv. Agatti-2002 was more affected $(\sim 41 \%)$ in the spring, while in autumn the $\mathrm{g}_{\mathrm{s}}$ was not affected in cv. Sadaf but markedly declined (30\%) in cv. Agatti-2002 in the GH conditions (Fig. 3).

The interaction of cultivars and $\mathrm{GH}$ conditions for leaf substomatal $\mathrm{CO}_{2}$ concentration $\left(\mathrm{C}_{\mathrm{i}}\right)$ was non-significant $(\mathrm{P}>0.05)$ for both seasons and all growth stages except during the autumn at seedling stage, when a significant $(\mathrm{P}<0.05)$ interaction of these factors was observed. Leaf $\mathrm{C}_{\mathrm{i}}$ was increased in both cultivars at all growth stages due to $\mathrm{GH}$ effect but $\mathrm{cv}$. Sadaf indicated a lower value of this parameter than cv. Agatti-2002. The $\mathrm{C}_{\mathrm{i}}$ increased greatly in cv. Agatti-2002 in autumn at seedling stage (23\%), during the spring at silking stage $(29 \%)$ and during the autumn at grain filling stage $(23 \%)$, while in cv. Sadaf it increased slightly at all these stages (Fig. 3).

\section{Discussion}

Significant interactions of the cultivars and treatments for different attributes appeared in one season and disappeared in another season at different phenological stages (Figs. 2 and 3; Tab. 1). This showed that the prevailing GH conditions produced a lot of changes in maize growth pattern as well as in the photosynthetic system, even though the effects were less in the heat tolerant (cv. Sadaf) than the sensitive cultivar (cv. Agatti-2002). In such conditions, plants undergo a depression in visual growth and development, but the extent of reduction depends greatly upon the type of stress, its severity and duration (AHMED et al. 2012, ArBonA et al. 2013, GALANI et al. 2013). Greater dry weight results from the extent of the available 
photosynthetic area together with an enhanced capacity of leaves to photosynthesize (KARIM et al. 2000, Huve et al. 2006, Suarez and Medina 2006).

The results of this experiment revealed that both of maize cultivars indicated quite a lot of changes in Chl- $a$, Chl- $b$, total Chls, Chl- $a$ /Chl- $b$ ratio and Car contents in both growing seasons and all growth stages (Fig. 2). Of two chlorophyll species, Chl- $b$ was more damaged than Chl- $a$ by prevailing GH high temperature condition (Fig. 2), leading to an overall loss of chlorophylls (Fig. 2), thereby causing more yellowing of leaves in cv. Agatti-2002 than in cv. Sadaf. These changes resulted in an increased Chl- $a$ /Chl- $b$ ratio (Fig. 2), which was slightly higher in spring at the seedling stage. It has been shown that high temperature enhances chlorophyllase activity, which degrades the chlorophylls and reduces their contents (Todorov et al. 2003, WAHID et al. 2007). Of the two chlorophyll species, Chl- $b$ is more prone to degradation by heat stress, especially during the spring when the temperature is sufficiently high and leaf nitrogen contents (not reported here) might have been reduced (MATILE and Hörtensteiner 1999). From these changes in the chlorophyll concentrations, it can be deduced that the sensitivity of Chl- $b$ to GH condition is mainly responsible for the yellowing of leaves, particularly in spring grown plant. From the prevailing temperature conditions in the canopy grown plants in spring compared to autumn, it can be seen that plants sown in spring months had to face more adverse temperatures at later growth stages (silking and grain filling), than the autumn grown plants, which do not experience such a high temperature and greater relative humidity during these growth stages (HuSsAIN et al. 2010). Thus, it can be inferred that GH conditions are more detrimental to the photosynthetic machinery of the spring sown plants in the warmer months.

Carotenoids have dual roles in plants. By acting as accessory light harvesting pigments, they harvest the light and funnel it onto the photosystem. The other important role of carotenoids remains the alleviation of oxidative damage to the biological membranes via the xanthophyll cycle (Havaux 1998). Environmental stress to the tolerant plants is reported to increase Car contents as compared to control counterparts, which suggests they have a role in the stress tolerance (WAHID 2007, ARBONA et al. 2013). In the present research, it was noted that tolerant maize (cv. Sadaf) in the GH conditions either showed increased, steady state or minimal decrease in Car contents during both the seasons as compared to sensitive maize (cv. Agatti-2002), which displayed decreased Car content in both the seasons. However, these decreases were more remarkable in the spring- than in the autumn-grown maize plants (Fig. 2). Thus, in concurrence with previous reports (WAHID et al. 2007), these data substantiated a crucial and profound role of carotenoids in the relatively adverse condition like $\mathrm{GH}$, where increased temperature and changes in $\mathrm{GH}$ are the main determinants of growth.

Plant productivity is assessed on the basis of efficiency of a plant to fix $\mathrm{CO}_{2}$ and production of photo assimilates by the leaves (source tissue) for export to various sinks for utilization and storage (RAJCAN and TollenaAR 1999, Luo et al. 2011). Maize, like a number of other crop plants, also shows great changes in $\mathrm{CO}_{2}$ fixation under suboptimal growth conditions (TollenaAr 1989, Sinsawat et al. 2004). In this study, the leaf gas exchange data revealed that the growing season and GH conditions had a great influence on these attributes of both the cultivars. Leaf $\mathrm{P}_{\mathrm{n}}, \mathrm{E}$ and $\mathrm{g}_{\mathrm{s}}$ were little affected at seedling, reduced more at silking and reduced the most at grain filling stage under GH conditions, while Agatti-2002 showed greater sensitivity to GH conditions during all the stages (Fig. 3). The $\mathrm{P}_{\mathrm{n}} / \mathrm{E}$ increased more in spring-grown maize than in autumn-grown maize (Fig. 3), whilst $\mathrm{Ci}$ indicated a 
greater decrease in spring than in autumn (Fig. 3). The data suggested that such declines in $\mathrm{CO}_{2}$ fixation by the sensitive maize was mainly due to reduced $\mathrm{g}_{\mathrm{s}}$ and reduced activity of Rubisco in absorbing $\mathrm{CO}_{2}$ and reduction of assimilate production via the Calvin cycle in the mesophyll cells (Douthe et al. 2011).

As mentioned above, both photosynthetic pigments and gas exchange parameters are the fundamental processes involved in dry matter yield. Therefore, optimal operation of reactions in both these processes is important. Studies highlighting the proportionate changes in these processes are scanty. In the present study, we noted that the pattern of changes in Chl$b$ was similar to the patterns of $\mathrm{g}_{\mathrm{s}}$ and $\mathrm{C}_{\mathrm{i}}$, which indicated that prevailing seasonal conditions were equally deterrent to all these attributes. Despite the fact that the photosynthetic pigment and gas exchange parameters are entirely different in nature and composition, these results show that parallel changes in both are important determinants of maize growth.

In conclusion, changes in the canopy temperature and relative humidity due to GH conditions were responsible for alteration in plant dry masses and photosynthetic attributes in maize, across spring and autumn season, although the latter was less adverse. The results have great implications in the production of such crop cultivars, which may be well adapted to upcoming changes due to $\mathrm{GH}$ effect.

\section{Acknowledgement}

This work was funded by Higher Education Commission (HEC), Islamabad, Pakistan by a studentship awarded to Iqbal Hussain (IH), PIN No. 042-160111-LS2-178. The work reported here is a part of the $\mathrm{PhD}$. dissertation of $\mathrm{IH}$.

\section{References}

Ahmed, A., Hassan, F., Aslam, M., Aslam, M. A., 2012: Physiological attributes based resilience of wheat to climate change. International Journal of Agriculture and Biology $14,407-412$.

Arbona, V., Manzi, M., De Ollas, C., Gómez-Cadenas, A., 2013: Metabolomics as a tool to investigate abiotic stress tolerance in plants. International Journal of Molecular Science 14, 4885-4911.

Blum, A., 1988. Plant breeding for stress environments. CRC Press, Boca Raton, Florida.

Crafts-Brandner, S. J., Salvucci, M. E., 2002: Sensitivity to photosynthesis in the C4 plant, maize to heat stress. Plant Cell 12, 54-68.

Davies, B. H., 1976: Carotenoids. In: Goodwin, T. W. (ed.), Chemistry and biochemistry of plant pigments, 138-165. Academic Press, London, NewYork, San Francisco.

Douthe, C., Dreyer, E., Epron, D., Warren, C. R., 2011: Mesophyll conductance to $\mathrm{CO}_{2}$, assessed from online TDL-AS records of ${ }^{13} \mathrm{CO}_{2}$ discrimination, displays small but significant short-term responses to $\mathrm{CO}_{2}$ and irradiance in Eucalyptus seedlings. Journal of Experimental Botany 62, 5335-5346.

Du, G. D., Lu, D. G., Zhao, L., WanG, S. S., CAI, Q., 2011: Effects of high temperature on leaf photosynthetic characteristics and photosystem II photochemical activity of kernelused apricot. Journal of Applied Ecology 22, 701-706. 
Galani, S., Wahid, A., Arshad, M., 2013: Tissue-specific expression and functional role of dehydrins in heat tolerance of sugar cane (Saccharum officinarum). Protoplasma 250, 577-583.

Ghannoum, O., Von Caemmerer, O., Ziska, L. H., Conroy, J. P., 2000: The growth response of $\mathrm{C} 4$ plants to rising atmospheric $\mathrm{CO}_{2}$ partial pressure: a reassessment. Plant Cell Environment 23, 931-942.

Havaux, M., 1998: Carotenoids as membrane stabilizers in chloroplasts. Trends in Plant Science 3, 147-151.

Hoagland, D. R., Arnon, D. R., 1950: The water culture method for growing plants without soil. Circ. 347, Univ. California, College of Agriculture, Berkeley, USA.

Hussain, I., Wahid, A., Ashraf, M., Basra, S.M.A., 2010: Changes in growth and yield of maize grown in the glasshouse. International Journal of Agriculture and Biology 12, 9-12.

Huve, K., Bichele, I., Tobias, M., Ninnemets, U., 2006: Heat sensitivity of photosynthetic electron transport varies during the day due to changes in sugars and osmotic potential. Plant Cell Environment 29, 1365-3040.

Karim, M. A., Fracheboud, Y., Stamp, P., 1999: Photosynthetic activity of developing leaves maize (Zea mays L.) is less affected by heat stress than that of developed leaves. Physiologia Plantarum 105, 685-693.

Karim, M. A., Fracheboud, Y., Stamp, P., 2000: Effect of high temperature on seedling growth and photosynthesis of tropical maize genotypes. Journal of Agronomy and Crop Sciences 184, 217-223.

Kim, S-H., Dennis, C. G., Richard, C. S., Jeffrey, T. B., Dennis, T. T., Vangimalla, R. R., 2007: Temperature dependence of growth, development and photosynthesis in maize under elevated $\mathrm{CO}_{2}$. Environmental and Experimental Botany 61, 224-236.

Luo, H-B., Ma, L., Xi, H-F., Duan, W., Li, S-H., Loescher,W., Wang, J-F., Wang, Li-J., 2011: Photosynthetic responses to heat treatments at different temperatures and following recovery in grapevine (Vitis amurensis L.) leaves. PLoS ONE 6, e23033.

Mahmood, S., Wahid, A., Rasheed, R., Hussain, I., Basra, S.M.A., 2012: Possible antioxidative role of endogenous vitamins biosynthesis in heat stressed maize (Zea mays). International Journal of Agriculture and Biology 14, 705-712.

Matile, P., Hörtensteiner, S., 1999: Chlorophyll degradation. Annual Review of Plant Physiology and Plant Molecular Biology 50, 67-95.

Morales, D., Rodrigues, P., Bellamico, J., Nichotes, E., Torrecillas, A., Sanchez-Blanco, M. J., 2003: High temperature preconditioning and thermal shock imposition affect water relations, gas exchanges and root hydraulic conductivity in tomato. Biologia Plantarum 47, 203-208.

Rajcan, I., TollenaAr, M., 1999: Source: sink ratio and leaf senescence in maize: II. Nitrogen metabolism during grain filling. Field Crops Research 60, 255-265.

SAlvucci, M. E., Crafts-Brandner, S. J., 2004: Inhibition of photosynthesis by heat stress: the activation state of Rubisco as a limiting factor in photosynthesis. Physiologia Plantarum 120, 179-186. 
Sinsawat, V., Leipner, J., Stamp, P., Fracheboud, Y., 2004: Effect of heat stress on the photosynthetic apparatus in maize (Zea mays L.) grown at control or high temperature. Environmental and Experimental Botany 52, 123-129.

Stone, P., 2001: The effects of heat stress on cereal yield and quality. In: BASRA, M. A., (ed.), Crop responses and adaptation to temperature stress, 243-291. Food Products Press, Binghamton, New York.

Suarez, N., Medina, E., 2006: Influence of salinity on $\mathrm{Na}^{+}$and $\mathrm{K}^{+}$accumulation, and gas exchange in Avicennia germinans. Photosynthetica 44, 268-274.

Szilvia, Z. T., Schansker, G., Kissimon, J., Kovács, L., Garab, G., Strasser, R., 2005: Biophysical studies of photosystem II-related recovery processes after a heat pulse in barley seedlings (Hordeum vulgare L.). Journal of Plant Physiology 162, 181-194.

TAiz, L., Zeiger, E., 2010: Plant Physiology, $4^{\text {th }}$ Ed. Sinauer Associates Inc. Publ. Massachusetts, USA.

Todorov, D. T., Karanov, E. N., Smith, A. R., Hall, M. A., 2003: Chlorophyllase activity and chlorophyll content in wild type and eti5 mutant of Arabidopsis thaliana subjected to low and high temperatures. Biologia Plantarum 46, 633-636.

TollenaAr, M., 1989: Response of dry matter accumulation in maize to temperature. Dry matter portioning. Crop Science 29, 1239-1246.

WAHID, A., 2007: Physiological implications of metabolites biosynthesis in net assimilation and heat stress tolerance of sugar cane (Saccharum officinarum) sprouts. Journal of Plant Research 120, 219-228.

Wahid, A., Gelani, S., Ashraf, M., Foolad, M. R., 2007: Heat tolerance in plants: An overview. Environmental and Experimental Botany 61, 199-223.

YAN, W., Hunt, L. A., 1999: An equation for modelling the temperature response of plants using only the cardinal temperatures. Annals of Botany 84, 607-614.

Yoshida, S., Forno, D. A., Cock, J. H., Gomez, V., 1976: Laboratory manual for physiological studies of rice. IRRI, Los Banos. 